\section{OPEN JOURNAL SYSTEMS}

ISSN:2237-2202
Available on line at Directory of Open Access Journals

Journal of Hyperspectral Remote Sensing v.8, n.1 (2018) 14-22

www.periodicos.ufpe.br/revistas/jhrs
Journal of Hyperspectral Remote Sensing

\title{
Evolution of anthropization in the "Corrente" river watershed between 1985 and 2010
}

\author{
Jaílson Silva Machado*, Gabriela Mateus de Fontes Silva**, João Batista Lopes da Silva*** \\ "Forest Engineer, Federal University of Piauí - UFPI, Bom Jesus - Piauí - Brazil. E-mail: jailson.mapas@gmail.com. \\ ${ }^{* *}$ MSc in Environmental Sciences and Technologies at the Federal University of Southern Bahia - UFSB. \\ E-mail: gabrielamfontes@yahoo.com.br. (Corresponding author). \\ ${ }^{* * *}$ D. Sc. Agricultural Engineering, Associate professor, Federal University of Southern Bahia - UFSB
}

Received 22 May 2018, accepted 23 May 2018

\begin{abstract}
This study aimed made a temporal evolution and intensity by anthropogenic process under native vegetation between 1985 and 2010, in the Corrente river watershed $\left(1,887.24 \mathrm{~km}^{2}\right)$, Piauí - Brazil. To make the image mosaics it was used images taken by the Landsat 5 TM sensor from different years $(1985,1990,2000$ and 2010). On the Landsat 5 TM images from basin was made the highlight of vegetation with Normalized Vegetation Difference Index (NVDI), and made a reclassification of NVDI images: disturbed and no disturbed areas. Then, it was processed the sum of all years of NVDI images classified. The results demonstrated rapid anthropogenic alteration in the area of the Corrente river watershed, main between the years 2000 to 2010. The reduction area of vegetation between 1985-2010 was $464.82 \mathrm{~km} 2$. Beside, there are areas with more than 20 years of anthropogenic process on the Corrente river watershed.
\end{abstract}

Keywords: NVDI, Savannah, crops.

\section{Introduction}

After the Atlantic Forest, the Cerrado is the Brazilian biome that suffered the most changes due to human occupation, due to the increasing pressure for the opening new areas aiming to increase the production of meat and grains for export, thus causing a progressive depletion of natural resources (CSR/IBAMA, 2009). Approximately 40\% of the 204 million hectares of Cerrado have been converted to cultivated pasture, agricultural areas and other types of use (Sano et al., 2009). In the last two decades the southern region of the states of Maranhão and Piauí, which are undergoing intensive occupation by the opening of new areas for the production of grains, especially soybean, promoting considerable spatial modifications (Elias, 2006). These changes have been promoting a number of environmental problems such as: habitat fragmentation, biodiversity decline, invasion of exotic species, soil erosion, aquifer pollution, ecosystem degradation, increased burning, carbon cycle imbalances and regional climate change (Klink and Machado, 2005).

The Cerrado is recognized for harboring the sources of important hydrographic basins in South America such as the Amazon, Platina and São
Francisco, and plays an important role in the issue of climate change due to its carbon absorption capacity (MMA, 2002). The native vegetation plays an important role in the interception, accumulation and drainage of rainwater, playing a fundamental role in the recharge of aquifers and maintenance of springs, and for this reason there is a greater concern regarding the use and occupation of the soil in the river basins. It is natural that territorial occupation distribution occurs in function of water resources, because the importance for socioeconomic activities, while population and production growth implies increasing pressures on natural resources, especially water resources. In this sense, studies related to anthropization in river basins and the resulting environmental impacts become increasingly important to encourage the adoption of measures that preserve natural resources and ensure their availability to human activities and to maintain ecological balance.

Monitoring tools for large areas and volumes of data, such as Geographic Information Systems (GIS), enable efficient and rapid treatment of environmental data, making it essential in environmental studies. Remote Sensing and Spatial Analysis tools make it possible to extract a large 
amount of georeferenced information to evaluate various features and components of the Earth's surface.

Rapid changes in landscapes make it difficult to monitor the environment, and it is necessary to use images at orbital levels. Silva et al. (2012) state that Remote Sensing (SR) techniques demonstrate good efficiency in monitoring large areas, because they have relatively low cost and easy data updating. The ease of acquiring metadata and spatial images of various satellites, available in the databases of the National Institute of Space Research (INPE) and the United States Geological Survey (USGS), allows to extract, treat information and generate new data from analyzes such as, for example, the temporal evolution of land use and occupation.

According to Goltz et al. (2007), Molin et al. (2010) and Bezerra et al. (2012), Vegetation Indexes are useful in the monitoring of natural resources, in the case of the Normalized Difference Vegetation Index (IVDN), it is taken into account the existing differences in the reflectance of the electromagnetic radiation of vegetation and soil at the infrared wavelengths close and red. In this case, the greater density of the forest cover, the lower the reflectance in the region of the visible (red) and the greater reflectance in the region of the InfraRed Next (IVP), due to the multiple scattering of the electromagnetic radiation in the different layers of the leaf (Bezerra et al., 2012). However, the monitoring of the intensity of resource use is also relevant in this type of analysis (Seabra and Cruz, 2013).
The particular location or resource holding time indicates its use intensity and consequently the degree of degradation, so the areas explored the longer possibly be more susceptible to environmental impacts. Thus, this study aimed to analyze the time course and intensity of use of the anthropic areas by the suppression of native vegetation in the "Corrente" stream basin in Cerrado of Piauí for the years 1985, 1990, 2000 and 2010. Using GIS and tools spatial analysis, vegetation indices were calculated by identifying regions that have suffered use changes and land use over the years. All work steps were performed using the Spatial Analyst extension of ArcGIS 10 software (ESRI, 2013).

\section{Materials and methods}

\subsection{Characterization of the study area}

The stream Corrente is a tributary of the Uruçuí Preto river, an important river in the region, which contributes significantly to the formation of the Parnaíba river (Elias, 2006). A Hydrologically Consistent Digital Elevation Model (MDECH) was used to delimit and reach the basin, which was based on topographic information from the SRTM (Digital Elevation Model) (USGS, 2011).

The area selected for this study is the catchment area of the Corrente stream, located in the south of the State of Piauí, covering the cities of Uruçui, Ribeiro Gonçalves and Baixa Grande do Ribeiro (Figure 1), comprising a total of $1,887.24 \mathrm{~km}^{2}$.

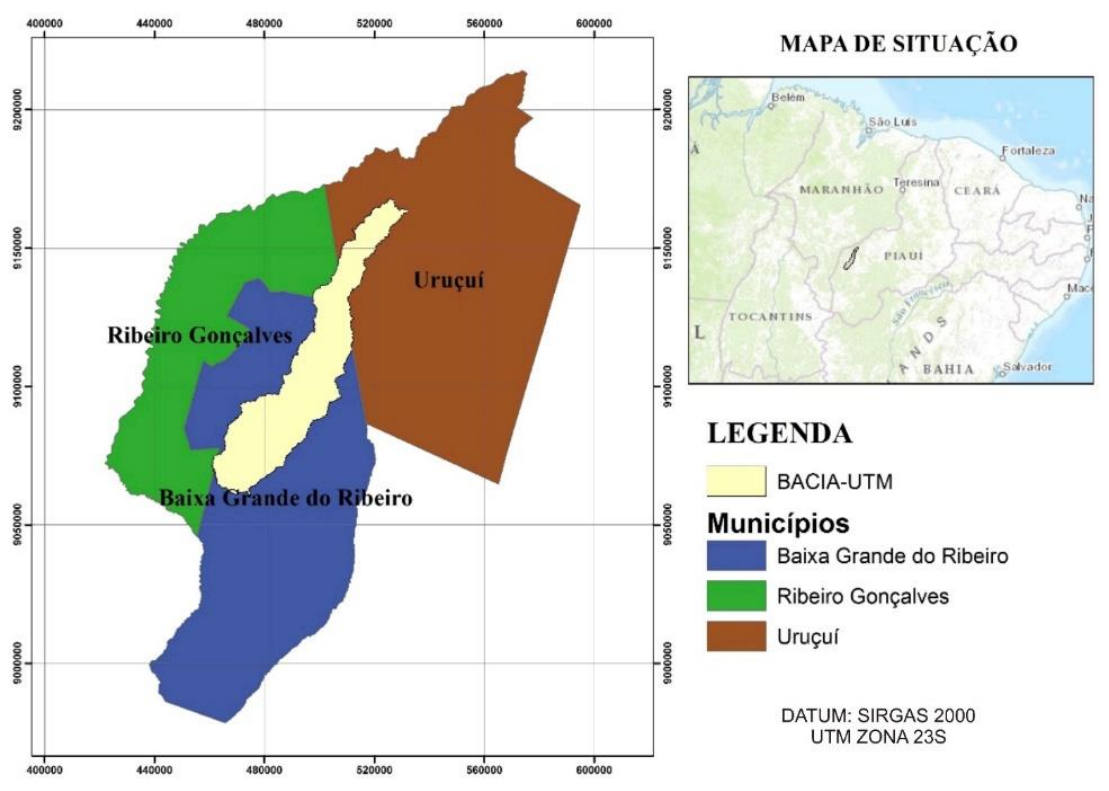

Figure 1 - Watershed situation map Corrente river with their cities of coverage. 
The native vegetation is characterized by the floristic of the Cerrado, but also has areas with characteristics of Caatinga, usually in the lower part of the mountain, and riparian forest, in the surroundings of the streams and near the center of the basin. Also called "Savannah Wooded", is a physiognomy subject to annual fire (IBGE, 2012).

2.2. Pre-Processing: Acquisition of images and atmospheric and geometric corrections

The images used were obtained by the TM sensor of Landsat 5 satellite with spatial resolution of $30 \mathrm{~m}$ and radiometric of 8 bits. The orbits of the images were 220, at points 66 and 65 . These images were acquired between August and September (months that are not realized agricultural crops in the region) of the years: 1985, 1990, 2000 and 2010. For each one, two spectral bands were used: band 3 - red region, and band 4 - near infrared region. The images were acquired free of charge from the electronic portal of the National Institute of Space Research (INPE, 2014). The images were registered with the extension "geotiff", before starting the pre-processing. For atmospheric correction, the model DarkObjectSubtraction (DOS) was used and implemented in ArcGIS 10 by Pereira (2014).

In geometric correction, initially made up the mosaic of images for the basin. The geometric correction or georeferencing of the study area was first carried out in the image of the year 1985, using as reference hydrographic data of the Corrente stream basin generated from the SRTM Digital Elevation Model (USGS, 2011). After the georeferencing of the image for the year 1985, it was used as the basis for the geometric correction for the images of the other years.

\subsection{Processing: Enhancement of vegetation}

After the pre-processing, was used the Index of Vegetation of the Normalized Difference (IVDN), proposed by Rouse et al. (1974), to emphasize the vegetation, which considers the differences of the reflective responses between vegetation and soil, considering that the vegetation has a higher reflectance in the near infrared region (band 4) and soil in the region of red (band 3). In this case, the greater the density of the forest cover, the lower the reflectance in the visible region (red), and the greater the reflectance in the InfraRed Next (IVP) region. The IVDN was obtained by equation (1) where:

$$
I V D N=\frac{I V P-V}{I V P+V}
$$

IVDN - Vegetation Index of Normalized Difference, IVP - Infra Red Region Near (Band 4 of the TM sensor), and V - Red Region (Band 3 of the TM sensor).

In this step the Raster Calculator tool was used to apply equation 1 directly on each pixel pair of bands 3 and 4 , resulting in pixels in the interval $[-1,1]$, with values close to 1 being the densest vegetation.

2.4. Analyzes: Classification of anthropic and vegetated areas and intensity of use

According to Jansen and Gregorio (2002), changes in Coverage and Land Use can occur in two ways. The first is the conversion from one use category to another. As for example, the change from forest cover to pasture. The second form is correlated to management, and would be change within the category itself, as an area that goes from small agricultural fields to irrigated agriculture.

The four images generated by the previous process, IVDN (equation 1), were reclassified through the reclassification tool of the reclass images, considering only two classes:

- Anthropized area: area with exposed soil, with low value in IVDN. Likely areas that demonstrate some process of human disturbance, fires, urban areas, pastures or some kind of crop, especially short-cycle crops, primarily soybeans, corn, rice and beans.

- Native vegetation: areas with high value in the IVDN, being areas with large amount of native vegetation, forest areas, among others.

After classification, to form an image that contains areas with higher land use time by human actions, the features values were assigned to each map using the "Reclassify" tool: to the disturbed sites (NDVI between - 1 and 0 ) was assigned the value of 1 and the vegetated areas (IVDN between 0 and 1) native was assigned the value 0 , then was made the algebraic sum of the four images. This procedure resulted in the map of accumulation of time of anthropization of the area, or intensity of use (Table 1). 
Table 1- Relationship between the algebraic sum of the classified images with IDVN time interval anthropization

\begin{tabular}{ccc}
\hline Values of the algebraic sum in the final time map of anthropization & Anthropogenic time interval \\
\hline 0 & 0 years \\
1 & 0 a 5 years \\
3 & 5 a 10 years \\
4 & 10 a 20 years \\
\hline
\end{tabular}

\section{Results and discussion}

The result of processing the images to generate maps NDVI expressing the range of values between -1 and 1, where values between $0-1$ to the lack of vegetation and from 0 to 1 most vigorous vegetation (Figure 2). Visually perceived change in the vegetation index over time, especially in the lateral areas of the basin.
The simple observation of Figure 2 shows the large areas in the first map with IVDN less than 0 that the occupation in the area ofthe basin by antropic activities exists since the period of 1985, or before. This indicates that despite a small amount, there was already interest in occupying the areas of the basin. A fact that corroborates with Aguiar and Monteiro (2005), who describes that the exploration in Cerrado begun in the 1970s and intensifying in the 1990s.
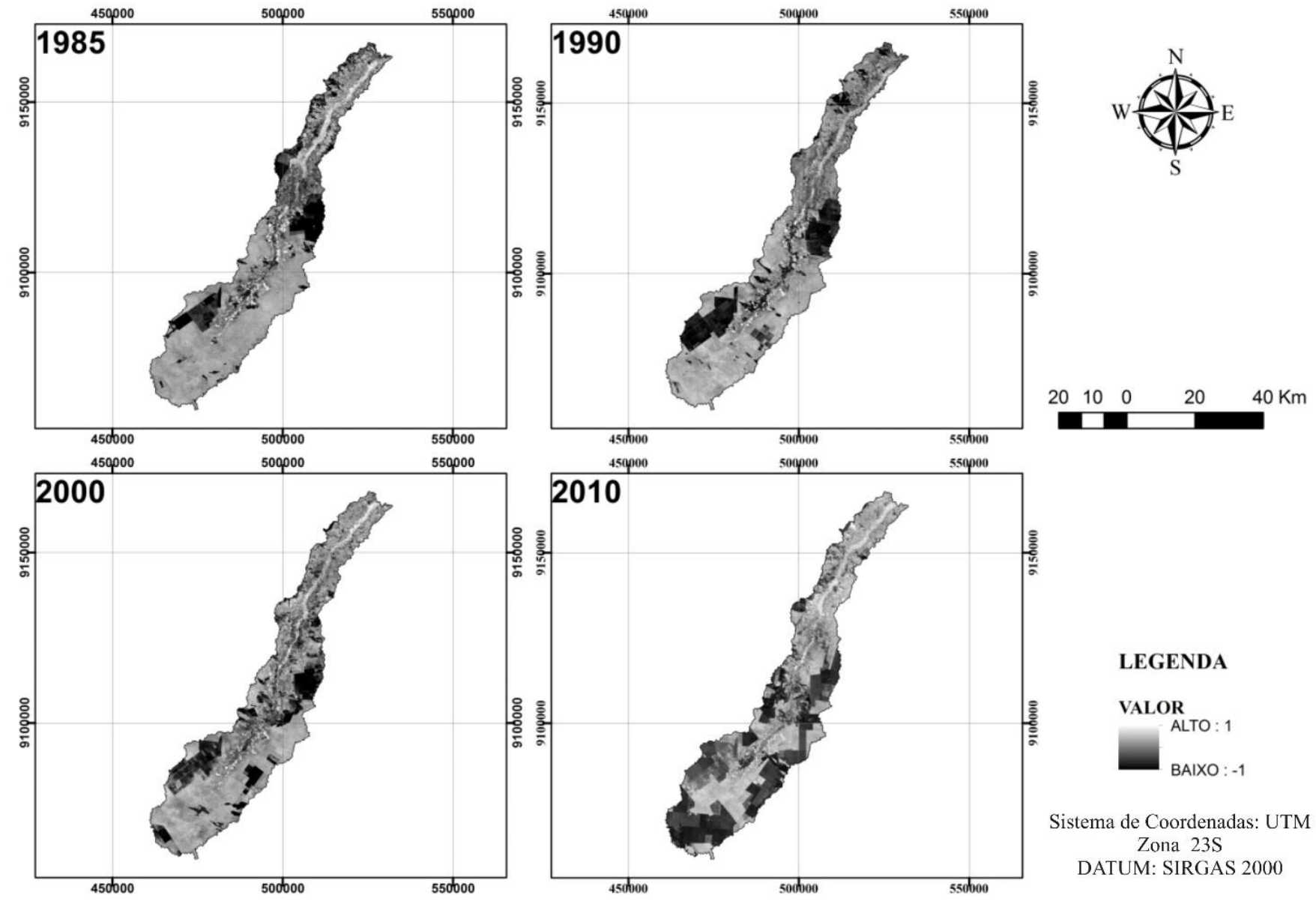

Figure 2 - Index of Normalized Difference Vegetation (IVDN) of the Corrente stream basin, Piauí, in the years 1985, 1900, 2000 and 2010. 
The reclassification of the images resulting from the IVDN (Figure 3) demonstrates the two classes in extreme contrast, where the decrease of the native vegetation class is observed gradually in addition to the anthropized class. In all the analyzed years it is noticed that in the areas near the water courses there are traces of degradation. Although the separation of features in the anthropogenic class has not been done, it is possible to infer that some of the areas identified with low vegetation index were areas of herbaceous or sub-shrub natural vegetation that may have been burned, due the period of drought in the region that occurs in the months analyzed (August and September) and where the presence of fire is common. This is an important aspect to be considered when talking about the Cerrado, because the accumulation of dry biomass during drought favors the occurrence of fires (natural, programmed / managed or criminal) (Silva et al., 2011).

This problem was diagnosed in the studies of Pereira and Gama (2010), where the authors analyzed the dynamics of deforestation and fires at the UruçuíUma and nearby Ecological Station, from 2003 to 2008, using images from CCD / CBERS-2 orbital sensors and TM / Landsat-5, saw constant burnings at the end of the dry season and deforestation in the vicinity of the Station.

Between the years 1985 to 2010 , there was an evolution of the feature culture / soil 266.76 to 518.42 $\mathrm{km}^{2}$, and cerrado reduction from $916.26 \mathrm{~km}^{2}$ in 1985 to $583.89 \mathrm{~km}^{2}$ in 2010 .
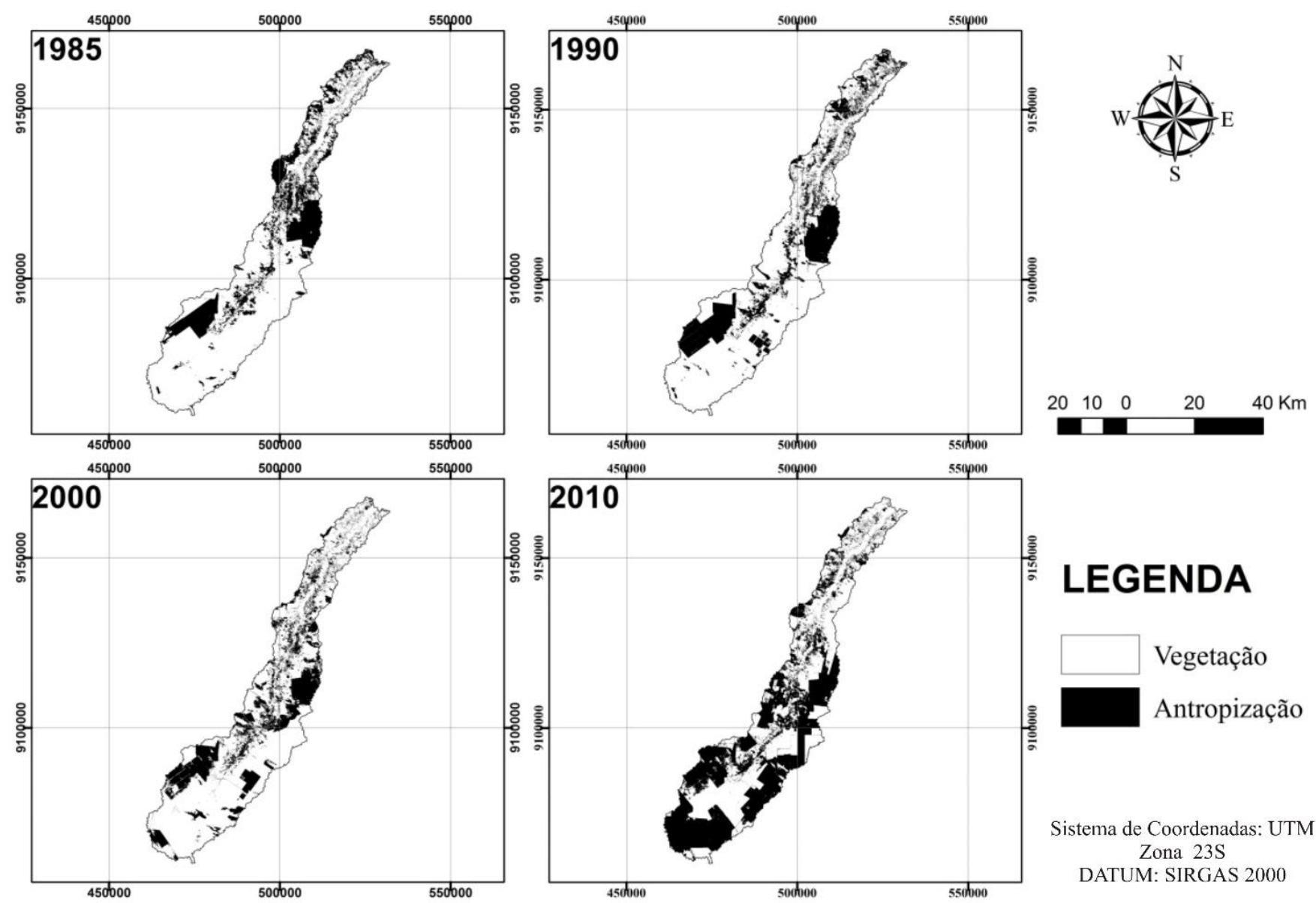

LEGENDA

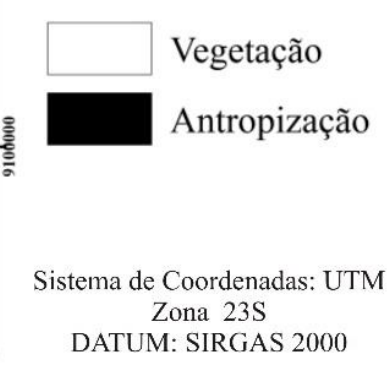

Figure 3 - Reclassification of IVDN images of the catchment area of Corrente stream in the years 1985, 1990, 2000 and 2010, in the classes anthropized area and native vegetation. 
Realizing that the Cerrado appears as a mosaic of several physiognomic forms (dirty field, closed field or grassland) where the predominance of these forms varies with the occurrence of fires and soil fertility, it is important to note that in this study the most open natural grassland formations were not considered, because these formations present low IVDN and were classified in the category "Anthropized" due to the

The anthropic and native vegetation areas in 1985 were 501,30 and $1,385.90 \mathrm{~km}^{2}$, respectively (Figure 4). In the year 1990, the anthropic and native vegetation areas were 549,13 and $1,338,13 \mathrm{~km}^{2}$, respectively, and did not change much in 2000, with the anthropic and native vegetation areas of 512.35 and $1375.14 \mathrm{~km}^{2}$, respectively. However, in 2010, these values increased to 966.17 (native vegetation) and 921.08 (anthropized area) $\mathrm{km}^{2}$, thus resulting in a more pronounced decrease in native vegetation areas. The anthropic area of $921.08 \mathrm{~km}^{2}$ in 2010 corresponded to $48.8 \%$ of the total area of the basin, similar to that of the municipality of Luíz Eduardo Magalhães-BA, which presents the same type and time of exploitation by agricultural crops, where $40 \%$ of cerrado areas in agricultural areas (Menke et al., 2009).

The results obtained (Figure 4) confirm what was demonstrated in the "Technical Report on Monitoring Deforestation in the Cerrado Biome, 20022008", where multispectral images were used to classify the evolution of Cerrado deforestation. This study classified Piauí as the fifth state that deforested the biome more between 2002 and 2008, and the three municipalities of Piauí contributed the most to the deforestation of the municipalities that cover the catchment area of the Currente stream: Baixa Grande of Ribeiro, in $11^{\circ}$, Uruçuí in $16^{\circ}$, and Ribeiro Gonçalves, in 82nd place in the national ranking (CSR/IBAMA, 2009).

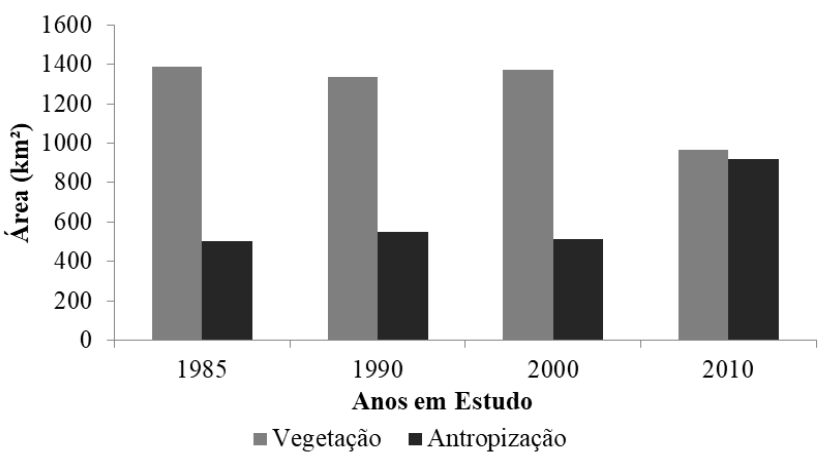

Figure 4 - Temporal evolution of vegetation and anthropogenic classes in the catchment area of the Corrente stream between 1985 and 2010. difficulty in distinguishing if the occurrence of these open forms occurred by overturning and / or intentional or natural burning, therefore in this study "vegetation" (Figure 3) is understood as the most dense vegetation forms, which did not affect the interpretation of the results, since a large part of the anthropic areas arises from fires or regional practice to use native herbaceous vegetation to graze animals during the dry season.

According to Aguiar and Monteiro (2005), Uruçuí is home to the largest grain production in the state of Piauí, due to the intense migration of entrepreneurs from other regions of the country with a high educational level, to manage agricultural projects. In Piauí Cerrado soy is the culture that excels in all areas of extracts, especially on farms larger than 1,000 hectares, contributing to the expansion of cash crops especially those geared for export. According to Menke et al. (2009), the expansion of this agricultural frontier in the Cerrado also influences non-anthropic areas, opening new areas, endangering the remaining native vegetation (Figure 3 ).

Therefore, although there is already evidence of anthropization in some areas in the year 1985, it was between 2000 and 2010 that the greatest occupation and change of use of this territory occurred. The studies used as reference point the monoculture focused on exports, mainly soybean, as the main factor of deforestation.

The results of the sum of the anthropic areas of all analyzed years (1985, 1990, 2000 and 2010) indicate which areas were most intensively exploited and could also indicate the areas most prone to soil degradation and pesticide contamination (Figure 5). Since this type of agricultural activity is associated to the intensive use of these substances that can accumulate time and cause contamination of soil and water (Soares and Porto, 2007). The intensified use of the area also indicates a potential contamination of the groundwater by pesticide leaching a fact that is worrying, since the great source of water in the region comes from wells. Thus, the map (Figure 5) allows to analyze the regions with the greatest impacts of anthropic activity, being of interest for studies and preventive / corrective measures of:

a) soil degradation: loss of soil / organic matter, erosion, compaction, desertification,

b) segradation of water resources: silting of watercourses, contamination by agrochemicals,

c) loss of biodiversity: habitat fragmentation, deforestation, etc. 


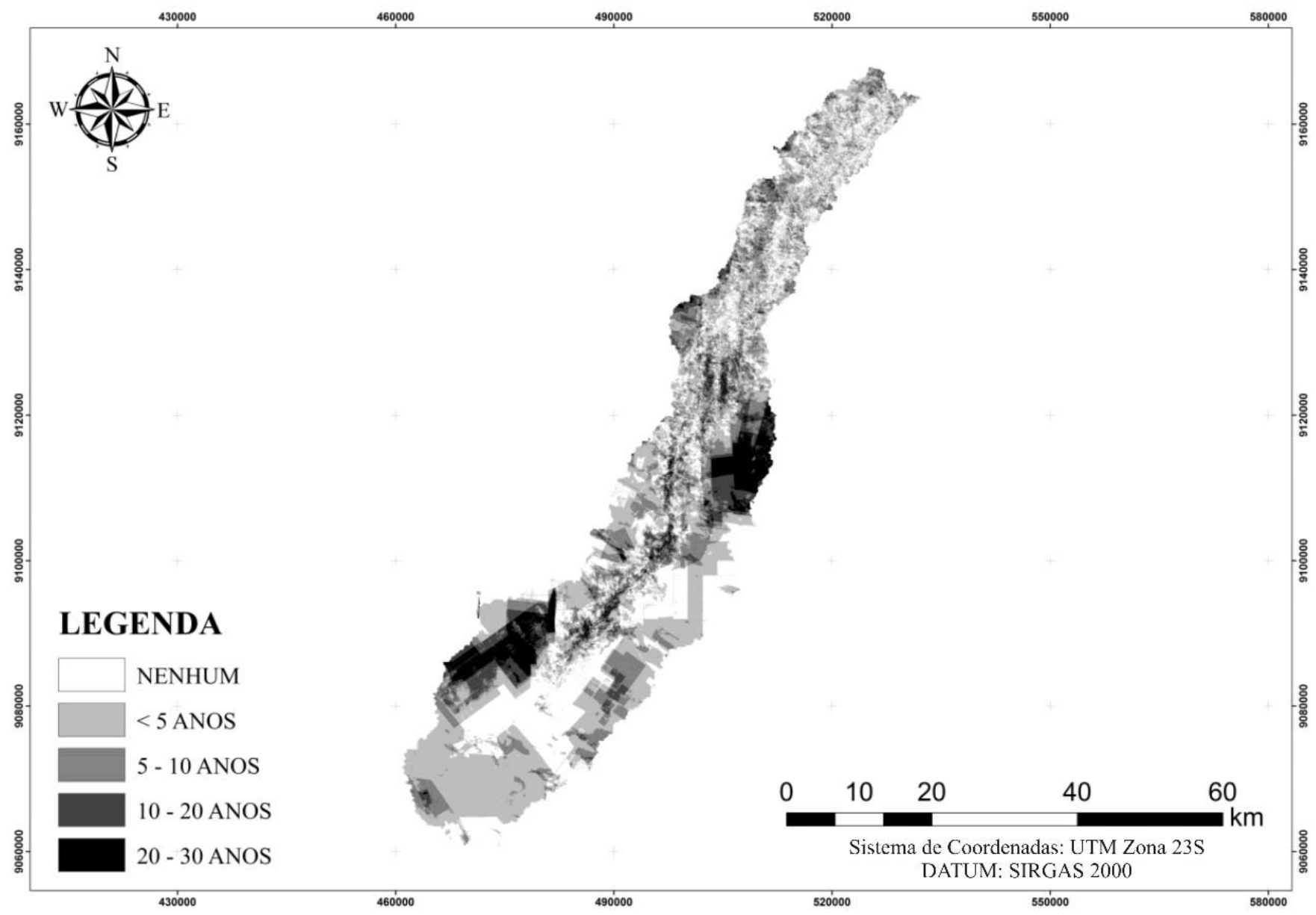

Figure 5 - Anthropized areas between 1985 and 2010 in the catchment Corrente Watershed, varying from 0 year of use to areas with more than 20 years of use.

Some areas of the basin, near the watershed limits were intensely disturbed and are used for mechanized conventional cultivation, which requires constant soil tillage and application of lime fertilizer, and some of these areas are identified on the map of Figure 5 and are being cultivated for more than 20 years. This intense conventional crop can alter the soil structure, tending to increase the chemical quality and reducing the physical quality of the soils. In this sense, the use of the map with the sum of time of the anthropic areas is a useful tool to carry out the environmental zoning for areas of risk of contamination and degradation.

In this methodology, the changes of use within the same class were not identified, for example, the abandoned or regenerated areas as well as areas with rocky or exposed soil, because they had low vegetation index and were classified as anthropized.
In 2010 there were still areas of native vegetation, that is, in the interval of 25 years they maintained a dense vegetation cover, however, parallel to them appear some areas that were intensely anthropized (Figure 5), these areas are located near the water courses, have a lower altimetric quota and are generally used for grazing with low technological level and still showed constant burn spots, according to Lima et al. (2009).

The values express that $6.6 \%\left(124.34 \mathrm{~km}^{2}\right)$ of the total area of the Corrente basin, are with anthropic activity process between 20 and 30 years, however, $25 \%\left(476.58 \mathrm{~km}^{2}\right)$ have never undergone occupation process. The areas with a recent occupation (less than 5 years) correspond to $39 \%\left(746.53 \mathrm{~km}^{2}\right)$, between 5 and 10 years $19.7 \%\left(371.84 \mathrm{~km}^{2}\right)$ and 10 to 20 years $8.9 \%$ $\left(167.96 \mathrm{~km}^{2}\right)$. Thus, despite being identified areas occupied since the first year of the study (1985), the occupation of the basin is recent, as the period of 
greatest activity in the soil occurred between 2000 and 2010.

\section{Conclusions}

Between 2000 and 2010, the greatest increase occurred in the anthropic areas, to the detriment of native vegetation areas in the Corrente stream basin. In 2010, the anthropogenic area reached $921.08 \mathrm{~km}^{2}$, which expresses almost $50 \%$ of the area of the basin. The occupation in the basin is recent, since the period of greatest activity in the soil was under 5 years of occupation in 2010 , which corresponds to $39 \%$ of the basin area. While only $25 \%$ of the area of the basin has never undergone anthropic occupation process.

The methodology used only considered the vegetation index (IVDN), which for the Cerrado, which has a vegetation characterized by grasses, shrubs and sparse trees, may present an overestimated anthropic data. Considering that these are the first areas to be used for agriculture or livestock, the result of this work is still relevant. In this case, it is suggested that there be a refinement in the methodology in order to avoid misinterpretations, especially regarding the targets of areas of natural pastures, rocky substrates associated with damaged reliefs with little vegetation cover, among other natural elements that present aspects similar to the spectral responses of anthropic areas.

The observed scenario is the expansion of agricultural areas and consequently the increase of environmental problems resulting from inadequate land use, in this sense, it is essential to apply a system of classification of land use capacity. One of the recommendations made in the Brazilian "Agenda 21" for the construction of sustainability in agriculture is the use of technological resources available to increase production without the need to incorporate new lands into the cultivated areas. Since monoculture for export predominates in the region, characterized by occupation of large areas, mechanization and use of agrochemicals.

The National Policy on Water Resources (Law 9433/97) highlights the guideline of integrating water resources management with environmental and land use management, with the planning and management unit in the river basin. Since the Hydrographic Basin is a unit of territorial management and water resources, the importance of the Hydrographic Basin Committees and other management instruments that allow the public power and the population to participate actively in the preservation of water is emphasized. In addition, the study of the basins allows identifying the main factors that interfere in the amount and quality of water available, proving the need to adopt measures to mitigate the impacts of land use and occupation in these intensely anthropized areas. Among these measures, River Basin Plans should consider measures to mitigate the fragmentation of ecosystems, such as creating incentives for rural producers that establish the Legal Reserve (RL) associated with the Permanent Preservation Area (APP), in areas that favor conservation of springs.

\section{Acknowledgments}

The authors of this paper are grateful to the Scientific Initiation Program of the Federal University of Piauí (PIBIC / UFPI) and to the Coordination of Improvement of Higher Education Personnel (CAPES) for financial support for the studies.

\section{References}

Aguiar, T.J.A., Monteiro, M.S.L., 2005. Modelo agrícola e desenvolvimento sustentável: a ocupação do cerrado piauiense. Ambiente \& Sociedade 8, 161-178.

Bezerra, E.F., Brandelero, C., Pereira, R.S., Sebem, E., Goergem, L.C.G., Benedetti, A.C.P., Leppert, D.B., 2012. Estimativa do volume total de madeira em espécie de eucalipto a partir de imagens de satélite Landsat. Ciência Florestal 22, 853-864.

CSR/IBAMA. Centro de Sensoriamento Remoto, 2009. Relatório Técnico de Monitoramento do Desmatamento no Bioma Cerrado, 2002 a 2008: dados revisados. Ministério do Meio Ambiente, Brasília.

Elias, D., 2006. Ensaios sobre os espaços agrícolas de exclusão. Revista Nera 9, 29-5.

ESRI, 2013. Tutorial do software ArcGIS. Disponível: http://www.esri.com/. Acesso: 8 ago. 2013.

Goltz, E., Brandão, D., Tomás, L., Mantelli, L.R., Adami, M., Shimabukuro, Y.E., Formaggio, A.R., 2007. Utilização de índices espectrais de vegetação do sensor MODIS na determinação de áreas suscetíveis a alagamento no Pantanal sulmatogrossense. Revista Brasileira de Cartografia 5, 3544.

IBGE. Instituto Brasileiro de Geografia e Estatística, 2012. Manual Técnico da Vegetação Brasileira, Brasil.

INPE. Instituto Nacional de Pesquisas espaciais, 2014 Catálogo de Imagens. Disponível: http://www.dgi.inpe.br/CDSR. Acesso: 6 jul. 2014.

Jansen, L.J.M., Gregorio, A.D., 2002. Parametricland cover and land use classifications as tools 
forenvironmental change detection. Agriculture Ecossystems e Environment 91, 89-100.

Klink, C.A., Machado, R.B., 2005. A Conservação do Cerrado Brasileiro. Megadiversidade 1, 147-155.

Lima, E.S., Lima, H.S., Ratter, J.A., 2009. Mudanças pós-fogo na estrutura e composição da vegetação lenhosa, em um Cerrado Mesotrófico, no período de cinco anos (1997-2002) em Nova Xavantina - Mt. Cerne 15,468-480.

Menke, A.B., Carvalho Junior, O.A., Gomes, R.A.T., Martins, E.S., Oliveira, S.N., 2009. Análise das mudanças do uso agrícola da terra a partir de dados de sensoriamento remoto multitemporal no município de Luis Eduardo Magalhães (BA Brasil). Sociedade \& Natureza 21, 315-326.

MMA. Ministério do Meio Ambiente, 2002. Agenda 21 Brasileira: Resultado da consulta nacional. Brasília: MMA/PNUD.

Disponível: http://www.mma.gov.br/estruturas/agenda21/_arqui vos/resultcons.pdf. Acesso: 23 jun. 2017.

Molin, J.P., Frasson, F.R., Amaral, L.R., Povh, F.P., Salvi, J.V., 2010. Capacidade de um sensor ótico em quantificar a resposta da cana-de-açúcar a doses de nitrogênio. Revista Brasileira de Engenharia Agrícola e Ambiental 14, 1345-1349.

Pereira, A.C., Gama, V.F., 2010. Anthropization on the Cerrado Biome in the Brazilian Uruçuí-Una ecological station estimated from orbital images. Brazilian Journal of Biology 70, 4, 969-976.

Pereira, O.J.R., 2014. Toolbox Para a calibração de bandas Landsat e correção atmosférica no ArcGIS. Disponível:

http:/geotecnologias.wordpress.com/2011/05/14/to olboxpara-a-calibracao-de-bandas-landsat-e- correcao-atmosferica-no-arcgi. Acesso: 6 jul. 2014.

Rouse, J.W., Haas, R.H., Schell, J.A., Deering, D.W., 1974. Monitoring vegetation systems in the great plains with ERTS. Proceedings of the Third Earth Resources Technology Satellite- 1 Symposium.

Sano, E.E., Rosa, R., Brito, J.L.S., Ferreira, L.G., 2008. Mapeamento semidetalhado do uso da terra do Bioma Cerrado. Pesquisa Agropecuária Brasileira 43, 153-156.

Sano, E.E., Rosa, R., Brito, J.L.S., Ferreira, L.G., 2009. Land cover mapping of the tropical savanna region in Brazil. Environmental Monitoring and Assessment 1, 1-12.

Seabra, V.S., Cruz, C.M., 2013. Mapeamento da dinâmica da cobertura e usoda terra na bacia hidrográfica do rio São João, RJ. Sociedade \& Natureza 25, 411-426.

Silva, C.R., Botrel, R.T., Martins, J.C., Machado, J.S., 2011. Identification and analysis of Burned areas in Ecological Station of Brazilian Cerrado, in: Grillo, O. (Ed.), Biodiversity Loss in a Changing Planet. InTech.

Silva, C.R., Lima, E.P., Machado, J.S., 2012. Análise temporal do espelho d'água da lagoa Parnaguá (PI) usando imagens digitais. Ambiência Guarapuava 8, 909-919.

Soares, W.L., Porto, M.F., 2007. Atividade agrícola e externalidade ambiental: uma análise a partir do uso de agrotóxicos no cerrado brasileiro. Ciência \& Saúde Coletiva 12, 131-143.

USGS. United States Geological Survey, 2011. Seamless data distribution system, Earth Resources Observation and Science. Disponível: www.usgs.gov. Acesso: 22 jan. 2011. 